Ana Dili Eğitimi Dergisi
Journal of Mother Tongue
Education
ADED - JOMTE
www.anadiliegitimi.com

\title{
Temel Dil Becerileri Eğitiminde Kullanılabilecek Aktif Öğrenme Öğretimsel İş/Taktikleri
}

\author{
Sedat Maden
}

\begin{abstract}
Özet
Bilgi birikiminin hızla artması bilgiye ulaşmayı ona sahip olmaktan daha önemli hâle getirmiştir. Bu ihtiyaç öğrenenin aktif olduğu bir öğretimin ve bilgiye ulaşmayı kolaylaştırıcı strateji, yöntem ve tekniklerin eğitim alanında kullanılmasını gerektirmiştir. Öğrenme süreci içerisinde öğrenciyi daha etkin hâle getiren yöntemlerden biri de aktif öğrenmedir. Bilgiye ulaşma konusunda temel dil becerilerinin önemi dikkate alındığında Türkçe öğretimiyle aktif öğrenme ilişkisinin kurulması zorunlu görünmektedir. Bu ilişkilendirme, öğrenenlerin hem dil becerilerinin gelişimine katkıda bulunabilecek hem de öğrenmeyi öğrenmelerine fayda sağlayabilecektir. Bu nedenle bu çalışmada aktif öğrenme yöntemine ait öğretimsel iş ve taktikler ile 2005 Türkçe Dersi Öğretim Programı'ndaki temel dil becerileri (dinleme/izleme, konuşma, okuma, yazma) amaç/kazanımları eşleştirilmiş; ayrıca bu iş ve taktiklerin Türkçe öğretiminde ne şekilde kullanılabileceğine yönelik örnekler sunulmuştur.
\end{abstract}

Anahtar sözcükler: Aktif öğrenme, Türkçe öğretimi, iş ve taktikler, dil becerileri, kazanım.

\section{Instructional Work and Tactics in Active Learning Used on Basic Language Arts \\ Education}

\begin{abstract}
Rapidly increasing of knowledge makes the reaching to knowledge more important than having of it. For this purpose, in education field it has been started to use strategies, methods and techniques in which the learner is active and provides reaching to the knowledge. One of these methods is active learning which make students more active in learning process. When the significance of basic language arts, on reaching the knowledge, is considered, it has to build a connection between Turkish language teaching and active learning. By means of this connection, it can be contributed to develop language arts of the learners, and be useful to learn the learning. Therefore, in this study it has been matched educational works and tactics of active learning method and the aims/acquisition of basic language arts (reading, listening/watching, speaking, and writing) in 2005 Turkish Language Curriculum. Besides it has been given some examples about how these tactics can be used in Turkish teaching.
\end{abstract}

Keywords: Active learning, Turkish teaching, work and tactics, language arts, acquisition.

\footnotetext{
* Doç. Dr., Giresun Üniversitesi, Eğitim Fakültesi, Türkçe Eğitimi Bölümü. E-posta: sedat.maden@giresun.edu.tr
} 


\section{Giriş}

Sürekli değişen yaşam şartları ile gelişen teknoloji mevcut bilgi birikimini de süratle artırmaktadır. Bu nedenle bilgiyi edinmekten çok bilgiye ulaşmak ve etkili kullanmak önemli hâle gelmiştir. Bu durum yetiştirilecek insan tipinin değişmesini ve bununla bağlantılı olarak eğitim anlayışlarının yenilenmesini gerektirmiştir. Günümüz dünyasında insan yaşamı bilgi ve teknolojinin etkisiyle yenilenmekte, şartlar ve imkânlar değişmektedir. Bu değişim insan yaşamını karmaşıklaştırmakta, çeşitlendirmekte ve ayrıntılarını artırmaktadır. İnsanın bu yaşam şartları içinde birbiriyle ilişkilendirilmemiş, ezberlenmiş bilgi kırıntılarına değil; birbiriyle ilişkilendirilmiş olan bilgiyi sentezleyerek yeni bilgiler ortaya çıkartabilmesi ve bunları problemlerin çözümünde kullanabilmesi, dolayısıyla alışkanlık ve beceri düzeyinde edinebilmesi önem kazanmıştır.

Çağdaş eğitim anlayışı, öğrenenin öğrenme sürecinde aktif rol almasını, kendi çözümlemeleri ile öğretmenin rehberliğinde doğruya ulaşmasını beklemektedir. Bu amaca hizmet eden eğitim biçimlerinden biri de aktif öğrenmedir. Aktif öğrenme, "öğrenenin öğrenme sürecinde kendi öğrenmesinin sorumluluğunu üstlendiği, öğrenene öğrenme sürecinin çeşitli yönleriyle ilgili karar alma ve öz düzenleme yapma fırsatlarının verildiği ve karmaşık öğretimsel işlerle öğrenenin, öğrenme sırasında zihinsel yeteneklerini kullanmaya zorlandığı bir öğrenme süreci" olarak tanımlanabilmektedir (Açıkgöz, 2006: 17). Kyriacou (1999) ise aktif öğrenmeyi “öğrencilere öğrenme süreci üzerinde önemli bir kontrol yetisi veren öğrenme etkinlikleriyle meşgul olma" olarak tarif etmektedir. Aktif öğrenme, salt tekrar ve alıştırmalarla sonucunda yapılan ezberciliği ve dış etkenlere dayalı öğretimi önleyerek kendi çabasıyla öğrenme sürecinde yer alan, düşünen, tartışan, iş birliği yapan, üreten, sorun çözen, yaratıcı ve eleştirel bakabilen bireylerin yetiştirilmesini ön plana çıkartmıştır.

Aktif öğrenme kavramı, John Dewey'in yaşayarak ve deneyime dayalı öğrenme çalışmalarıyla birlikte, eğitim yaklaşımlarını ve program düzenlemelerini etkilemiştir. John Dewey, çalışmalarında okulda küçük bir toplum yaratmayı hedeflemiş ve bu doğrultuda bir aktivite-eyleme dayalı öğretim programı hazırlamış ve kullanımını önermiştir. Bu programda öğretmenlerin demokratik bireyler olması gerektiğini savunmuştur. Öğretmenlerin deneyimlerini, öğrenciler için gerekli olan yetenekleri kazandırmak amacıyla iş birliği içerisinde paylaşmalarını ve bunun demokratik yollarla olması gerektiğini savunmuştur (Page, 1990: 19). 20. yüzyılın başlarında William H. Kilpatrick, öğrenmenin temelinde daima eylem ve deneyim olduğunu söylemiştir. Bununla birlikte pasif bir öğrenmenin yerine aktif öğrenmenin öğrenci üzerinde daha etkili olduğunu belirtmiştir (Page, 1990). Aktif öğrenme "dinlemekten" daha çok "yapmak" ile ilgilidir. Öğrenciler okumalı, yazmalı, tartışmalı veya problemin çözümü ile meşgul olmalıdır. En önemlisi ise analiz, sentez ve değerlendirme vazifesini üstlendikleri düşüncesi, zihinlerinde yer etmelidir (Bonwell ve Eison, 1991; Ercan, 2004). Tüm bu yeterlilikleri bireye / öğrenciye uygulamalı, yaparak-yaşayarak ve iş birliğine dayalı bir öğrenme süreci sağlayabilir. Dolayısıyla öğreneni hem fiziki hem de zihinsel olarak sosyal anlamda aktifleştiren, pasif ve tek yönlü öğrenme sürecini kabul etmeyen aktif öğrenme, üst düzey düşünme becerilerini kazanmayı sağlayacak özelliklere sahiptir. Aktif öğrenme, öğrencileri yapılan uygulamaların merkezine yerleştirdiği için öğrenme, bireysel ve grup sorumluluğu ile çözüm üreterek kalıcı hâlde gerçekleşmektedir. Bu aşamada öğrenme sürecinin etkililiğini artırmak için her türlü araç-gereç ve teknoloji kullanılabilmektedir.

Öğrenilenlerin yerleşik alışkanlıklar biçiminde kalıcı olması ile ilgili McNeil ve Wiles (1990)'in yaptığı araştırmada, hatırda tutmaya etkisi bakımından, anlatma (düz anlatım) yönteminin \% 5, okuma yönteminin \% 10, işitsel materyaller kullanmanın \% 20, gösterme yönteminin \% 30, görsel materyal kullanma ve bu materyalleri yorumlama yönteminin \% 50, tartışma yönteminin $\% 70$, yaparak öğrenme yönteminin \% 75, öğrendiklerini farklı durumlarda kullanma ve başkalarına öğretme yönteminin de \% 90 oranda etkiye sahip olduğu tespit edilmiştir (Güçlü, 2007). Söz konusu araştırma öğrencilerin sürece aktif katılımının öğrenilenlerin kalıcı olmasında \% 75-90 oranında etkili olduğunu göstermektedir. 
Aktif öğrenme bir öğretim yöntemi olarak kabul edildiğinde, diğer öğretim biçimlerine göre önemli farklılıkların olduğu görülmektedir. Aktif öğrenme, beynin çalışmasına uygunluğu, yaşam boyu öğrenmeyi temele alması, kullanılışlı ve ekonomik olması, öğretimsel iş ve taktikler açısından destekleyici yönlerinin olması, yaparak-yaşayarak öğretmesi, birikimli olarak ilerlemesi, öğrencinin özelliklerini dikkate alması, eleştirel düşünme, yaratıcılık ve problem çözme becerilerinin gelişmesine önem vermesi, öğretmen ve öğrenciye yüklediği sorumluluklar gibi açılardan farklı bir öğretim şeklidir.

\section{Aktif öğrenme ortamında öğretmen ve öğrenci}

Öğrenenin zihinsel becerilerini harekete geçiren, yaparak yaşayarak öğrenmeyi hedefleyen ve tecrübe edinmeye önem veren aktif öğrenme ortamında başarıya ulaşmak için öğretmen ve öğrenci açısından önem arz eden bazı gereklilikler bulunmaktadır:

$\checkmark$ Öğretmenler bilgiyi kavramlaştırmalı ve görevlerinin sadece inşa sürecini yürütmek olduğunu, bilgi vermek olmadığını bilmelidir.

$\checkmark$ Öğretim, öğrenme için en uygun ortamı yaratmak anlamına gelmelidir. Öğretim, sınıf / okul duvarları ile sınırlandırılmamalıdır. Okul / ders dışı informal öğrenme ortamları da öğrenme amaçlı değerlendirilmelidir. Öğretme etkinliklerinde aile ve toplumun katılımı da mümkün olmalıdır. Okul, aile ve toplum iş birliği ile öğrenme desteklenmelidir.

$\checkmark$ Öğretmen bilginin tek kaynağı / merkezi değil, daha ziyade yol göstericisi / kılavuzu olmalıdır.

$\checkmark$ Çocukların topluluk içinde daha iyi öğrendikleri bilinmektedir. Bu nedenle grup çalışmaları ve proje takımları, sınıf ilişkilerini sistematik olarak çözümlemek ile deneyimleri ve değerleri incelemek için kullanılmalıdır.

$\checkmark$ Öğrencilerin kişisel tecrübelerle edindikleri bilgiler en kolay özümsenenlerdir. Bu nedenle, çocuğun ön bilgilerini anlamak ve yenileriyle eski bilgileri bütünleştirmek önemsenmelidir.

$\checkmark$ Öğrenciler bilişsel ve fiziksel açıdan aktif olarak öğrenime katılmalıdır.

$\checkmark$ Öğrencilerin ilgi, güdülenme ve ihtiyaçlarına göre öğretim süreci şekillenmelidir.

$\checkmark$ Öğretmenler öğrencilerin düşünme, mantık yürütme, karar verme, yansıtma, anlam çıkarma ve problem çözme becerilerini teşvik etmelidir (Pillay, 2001).

Aktif öğrenme uygulamaları ile öğretim yapılırken öğrencinin özellikleri, öğretim ortamının tasarımı, öğretmenin özellikleri ve program açısından bazı hususlara önem verilmelidir. Bu hususlara dikkat edildiğinde aktif öğrenme istenilen düzeyde gerçekleşebilir:

\footnotetext{
$\checkmark$ Öğrencilerin hazır bulunma düzeylerini gözden geçirmek

$\checkmark$ Öğrencilerin ilgi ve dikkatini sürecin başında, içinde ve sonunda canlı tutmak

$\checkmark$ Sorumluluk alma ve paylaşmaya davet etmek

$\checkmark$ Öğrencilere dersin hedeflerini açıklamak

$\checkmark$ Dersi akıcı planlamak

$\checkmark$ Anlama ve anlatma düzeyini değerlendirebilecek materyaller kullanmak

$\checkmark$ Çabuk ve etkili ilerlemek

$\checkmark$ Aşamalı olarak öğretim yapmak

$\checkmark$ Geri bildirim yaparak önceki bilgilerle ilişki kurmak

$\checkmark$ Çeşitlilik sunmak
} 
$\checkmark$ Etkili ve uygun şekilde soru sormak

$\checkmark$ Soru sorarak ve performansları değerlendirerek dönüt sağlamak

$\checkmark$ Öğrencilerin iletişim ve etkileşimde olmasını sağlamak

$\checkmark$ Öğrenciye araştırmalarında özgürlük tanımak

$\checkmark$ Çalışma ve paylaşım grupları oluşturmak

$\checkmark$ Uzun ve karmaşık kuramsal açıklamalardan kaçınmak

$\checkmark$ Öğrencilerin grup çalışmaları ve akranlarıyla çalışma yapmalarını sağlamak

$\checkmark$ Kavramlar ve genellemeler üzerinde odaklanmak

$\checkmark$ Öğrenilen bilgilerin kullanıldığı uygulamalar yapmak

$\checkmark$ Akranlarına sorma ve yardım almayı teşvik etmek

$\checkmark$ Görsel-işitsel materyaller oluşturmak ve kullanmak (Martyn, 2007; Slavin, 2003; Saban, 2005).

Aktif öğrenmede, hedeflenen öğretimi gerçekleştirmek için çeşitli teknikler kullanılmaktadır. Aktif katılımı sağlayan kartopu, istasyon, köşelenme, tereyağ-ekmek, sandviç, Phillips 66, vızıltı, akvaryum, pazar yeri, soru turu, dönüşümlü öğretme, kum saati gibi birçok teknik bunlar arasında sayılabilir. Bu teknikler aktif öğrenmenin temel öğretim felsefesinin sınıfta uygulanış biçimleridir. Bunun yanında aktif öğrenme, tekniklerin işlerliğini ve diğer öğretim yöntemlerinin etkililiğini yükseltmek için öğretim sürecinde bazı öğretimsel iş ve taktiklere de başvurur. Öğretimsel iş ve taktikler, öğretim yöntem ve tekniklerinin içeriğini oluşturmaktadır (Açıkgöz, 2006: 85). Bu öğretimsel iş ve taktikler, bir yöntem veya teknik kadar detaylı, zaman alııı, kapsamlı çalışmalar değildir. Bir öğretim tekniği içinde kullanılabilecek küçük pratik etkinliklerdir. Slogan bulma, reklam hazırlama, net olmayan açıklamalar, görsel imge oluşturma, nedenleri bulma, soruyu ya da problemi bulma, soru çıkarma, görüş tarama gibi...

\section{Temel dil becerilerinin eğitimi ve aktif öğrenme}

Aktif katılımla, öğrenilenlerin yerleşik alışkanlık ve beceri hâlinde kazandırılmasının âdeta bir olduğu alanlardan biri de temel dil becerilerinin eğitimidir. Temel dil becerilerinin eğitim / öğretiminde ya da özel olarak Türkçe öğretiminde, öğrenme sürecini aktif hâle getiren, öğrenenin özelliklerine göre şekillenen, uygulamalı, hareketli ve birikimli ilerleme sağlayan aktif öğrenme yönteminin kullanılması temel dil becerilerinin kalıcı olarak kazanılmasında ve geliştirilmesinde etkili olacaktır. Temel dil becerileri (dinleme, konuşma, okuma, yazma) birbiriyle ilişki içinde gelişen ve birbirini destekleyen ancak kendine özgü ilkeleri olan birer öğrenme alanı olarak kabul edilmelidir. Her birinin farklı gelişim özellikleri bulunmaktadır. Bu nedenle temel dil becerilerinin öğretiminde değişik öğretim yöntem, teknik ve bunlara bağlı etkinliklerin kullanılması zorunludur.

Aktif öğrenme yönteminin dil öğretimi ve iletişim becerilerinin geliştirilmesine yönelik faydalı yönleri olduğu alan yazınında yapılan araştırmalarda tespit edilmiştir (Kalem ve Fer, 2003; Maden, 2011; Özerbaş, Tabak ve Ahi, 2010). Aktif öğrenme yöntem, teknik, öğretimsel iş ile taktiklerinin temel dil becerilerinin kazandırılması ve geliştirilmesinde kullanımı iletişim odaklı, karşııkı anlaşmaya dayalı, bireysel ve grup hâlinde problem tespit etme ve çözüm üretme imkânına sahip, hayatilik ilkesine uygun, sadece bedenen değil zihnen de aktif olmayı sağlama açısından da gereklidir.

Dil eğitimi ve öğretimi, uzun bir süreçtir ve bu süreçte, hangi öğretim şekillerinin kullanılacağı büyük öneme sahiptir. Dil öğretimi yaklaşım ve teorilerinin büyük bir bölümü, öğretim şekillerinin ekonomik, siyasal, sosyal değişim ve eğitimde yaşanan gelişmelerden payını alarak asıl değerini kazandığını, dil öğretim yöntemlerinin pratik, sezgi ve yaratıcılık açısından güçlü olması gerektiğini savunur. Bununla birlikte dil öğretim yöntemlerinin ve tekniklerinin hayat boyu öğrenmeyi desteklemesi ve doğal yaşam alanına uygun etkinliklerle öğretimi gerçekleştirmesi hedeflere ulaşmak 
için zorunludur. Bu özelliklerden yoksun olan dil öğretimi ve öğrenmeyi merkeze almayan yöntem ve teknikler ilgi görmemektedir. Değişen ve gelişen sosyal, ekonomik koşullar ile eğitim alanındaki gelişmelerden dolayı dil öğretiminde kullanılacak yöntem ve teknikler de yenilenmeli ve gereksinimlere cevap verebilmelidir. Öğretmenlerin dil öğretim sürecinde yöntem ve teknikleri, etkin ve verimli şekilde kullanabilmeleri için öğrencilerin özelliklerini ve işleyecekleri konuyu iyi bilmeleri, ayrıca etkili iletişim kurabilmeleri gereklidir. Ancak, bu şekilde en doğru yöntem ve tekniği bularak dil öğretiminde başarıya ulaşılabilir (Liu ve Shi, 2007).

Temel dil becerilerinin eğitiminde, farklı durumlarda anlama ve anlatma becerilerini yaparakyaşayarak edinmeye yardımcı olan, farklı öğretim biçimi alternatifleriyle dersi zevkli hâle getiren aktif öğrenme teknikleri ve uygulamalarına yer vermek faydalı olacaktır. Günümüzde Türkçe öğretiminde temele alınan yapılandırmacı yaklaşım da aktif öğrenmeyi desteklemektedir. Yapılandırmacılığa göre dil doğuştan edinilmemekte veya şartlandırma yoluyla kazanılmamakta, aksine bireyin aktif çabalarıyla öğrendiği bir özellik ve sosyal etkileşim aracı olarak kabul edilmektedir. Yapılandırmacılık, dil eğitiminde öğrenenin içinde bulunacağı ortam ve sosyal ilişkiler bağının önemini vurgulamakta, öğrencilerin kendilerini özgür, rahat hissedebilecekleri, kendilerine değer verildiğini hissedecekleri ve öğrenme ortamının bir parçası olarak kendilerini görebilecekleri bir süreçte başarılı olunabileceğini kabul etmektedir. Bunun için soyut kural ve açıklamalardan ziyade gerçek eylem / etkinlikler / durumlar gereklidir. Bu gereklilik aktif öğrenmenin eğitim ilkelerini ön plana çıkarmaktadır: Bireysel özerklik, iş birliği, etkinlik temelli öğretim, problem çözme, eski-yeni bilgiler arasında özgün bağlantılar kurma, deneyimlerden yararlanma, sorumluluk alma, paylaşma, eleştirel ve yaratıcı düşünme, demokratik atmosfer gibi. Diğer bir deyişle, aktif öğrenme geçmiş bilgilerle yeni bilgiler arasında bağ kurarak öğrencinin aktifleşmesi ile öğrenmeyi desteklemektedir.

\section{Araştırmanın Amacı}

Söz konusu gerekçelerden hareketle araştırmada, aktif öğrenme öğretimsel iş ve taktiklerinin, Türkçe öğretimi amaç ve kazanımlarına uygunluğu ile temel dil becerilerinin kazandırımasında ve geliştirilmesinde kullanılabilirliğinin değerlendirilmesi amaçlanmıştır.

\section{Yöntem}

Araştırmada nitel araştırma desenlerinden doküman analizi kullanılmıştır. Kuramsal uygulama öneri ve değerlendirmeleri içeren araştırmada, alan yazınında aktif öğrenme üzerine hazırlanmış, yaygın kullanıma sahip olduğu tespit edilen bir eser doküman incelemesine tabi tutulmuştur. Araştırmada incelemeye alınan aktif öğrenme öğretimsel iş ve taktikler için Açıkgöz (2006: 85-123)'ün "Aktif Öğrenme" eserindeki ilgili kısımlardan yararlanılmıştır. Ancak araştırmada, bahsedilen kaynakta geçen tüm öğretimsel iş ve taktikler değil, temel dil becerilerinin kazandırılmasında uygulanabilirliği dikkate alınarak bazıları değerlendirmeye alınmıştır.

\section{Bulgular}

Öğretimsel taktik ve işlemlerin hangi temel dil becerisinin öğretiminde daha yararlı olabileceğine yönelik değerlendirme aşağıda verilmiştir. İncelemede örnek olarak kabul edilmiş aktif öğrenme öğretimsel iş ve taktiklerinin belirlenen kazanımlar dışındaki dil becerilerini (kazanımlarını) edindirmede, farklı uygulamalar aracılığıyla etkili olabileceği de dikkate alınmalıdır.

Tablolarda "Etkili Olabileceği Amaç / Kazanımlar" başlı̆ı altında verilen kısaltmalarda harf kodları, öğrenme alanını (Dinleme, Konuşma, Okuma, Yazma); ilk sayı amacı, ikinci sayı ise kazanımı ifade etmektedir. Örnek olarak; K.2.2: Konuşma Alanı, 2. Amaç, 2. Kazanım gibi. 


\section{Temel Dil Becerilerinin Eğitiminde Kullanılabilecek Öğretimsel Taktik ve İşlemler}

\section{Slogan bulma}

Tanım: Slogan, "bir düşünceyi kolay hatırlanıp tekrarlanabilir bir biçimde ifade eden kısa, çarpıcı söz" (TDK-Türkçe Sözlük, 2005) olarak tanımlanmaktadır. Öğrencilerden işlenen konunun ana düşünce, duygusuyla ve önemli kısımlarıyla ilgili bir slogan üretmelerini kapsayan bir işlemdir.

\begin{tabular}{lc} 
Kullanımı & $\begin{array}{c}\text { Etkili Olabileceği } \\
\text { Amaç / Kazanımlar }\end{array}$ \\
\hline Slogan Bulma, öğretime hazırlayıcı ve ders sürecindeki & $\mathbf{K . 2 . 2}$ \\
dikkati, ilgiyi artırıcı bir işlem olabilir. Okunacak veya & $\mathbf{K . 2 . 4}$ \\
yazılacak bir metinle ilgili öğrencilerin özgür bir şekilde & $\mathbf{K . 2 . 5}$ \\
slogan üretmeleri, bu sloganı istedikleri ses tonuyla & $\mathbf{K . 2 . 7}$ \\
seslendirmeleri veya yazılı olarak arkadaşlarına iletmeleri & $\mathbf{K . 2 . 8}$ \\
istenildiğinde, öğrenciler hem metnin içeriğini merak eder & $\mathbf{K . 2 . 9}$ \\
hem de öğrendiklerini düşünerek metni yeniden incelemeye & $\mathbf{0 . 1 . 1}$ \\
başlayabilirler. Aynı zamanda temel dil becerilerine ait & $\mathbf{0 . 1 . 3}$ \\
sloganlar oluşturarak dersin ilgili bölümlerinde geçişlerin & $\mathbf{0 . 1 . 4}$ \\
sloganlarla yapılması da güdülenme ve dikkati artırabilir. & $\mathbf{0 . 2 . 2 4}$ \\
\hline
\end{tabular}

\section{Net olmayan açıklamalar}

Tanım: Öğretmenin konunun bir kısmını net olarak açıklayıp gerisini kapalı bırakması, öğrencide merak uyandırıp onu araştırmaya yöneltmesidir.

\begin{tabular}{lc}
\hline Kullanımı & $\begin{array}{c}\text { Etkili Olabileceği } \\
\text { Amaç / Kazanımlar }\end{array}$ \\
\hline Öğretmenin derste işlenen bir konu ile ilgili net olmayan & \\
açıklamalar yapması öğrencileri meraka ve düşünmeye sevk & \\
edecek bir işlemdir. Türkçe dersinde bir metin yazmaları için & \\
öğrencilere net olmayan veya eksiltili kısımlar aktarılarak & \\
öğrencilerin bu kısımları veya düşünceleri netleştirip yazıya & $\mathbf{0 . 2 . 2 4}$ \\
dökmeleri istenebilir. Bu çalışma yazılı anlatım sürecinde & Y.2.3 \\
kullanılabileceği gibi okuma becerisi için de kullanılabilir. & Y.3.1 \\
Okuma metni okunmadan önce içerikle ile ilgili net olmayan & Y.3.2 \\
açıklamalar yapılır, öğrencilerin bu açıklamalardan yargıya & Y.3.3 \\
varmaları istenerek okuma eylemine geçilebilir. Aynı & Y.3.4 \\
zamanda öğrencilerin sözlü anlatım becerilerini geliştirmek & \\
için bir olayla, haberle, istekle, hayalle vb. ilgili net olmayan & \\
bir açıklama yapııı.ı̈. Öğrencilerin sözlü olarak bu konudaki & \\
gelişmeyi sürdürmeleri istenebilir. & \\
\hline
\end{tabular}




\section{Reklam hazırlama}

Tanım: Öğrencilerin işlenen konuya ilişkin televizyonda ya da gazetede tanıtıcı reklamlar(Bir şeyi halka tanıtmak, beğendirmek ve böylelikle sürümünü sağlamak için denenen her türlü yazı, resim, film vb.) tasarlamasıdır.

\begin{tabular}{|c|c|}
\hline Kullanımı & $\begin{array}{c}\text { Etkili Olabileceği } \\
\text { Kazanımlar }\end{array}$ \\
\hline $\begin{array}{l}\text { Reklamlar, her yaştaki insanın ilgisini çektiği gibi çocukların } \\
\text { da ilgisini çekmektedir. Küçük yaştan itibaren çocukların } \\
\text { televizyondaki reklamları takip ederek çeşitli sözcükleri } \\
\text { söylemeye veya şarkı söylemeye çalışmaları bunu } \\
\text { göstermektedir. Türkçe dersinde de çocukların konu ile ilgili } \\
\text { görsel unsurlar içeren, sesli ve canlandırmalara dayalı bir } \\
\text { reklam geliştirmeleri dersteki güdülenmeyi ve iletişim } \\
\text { becerilerini kazanmada etkili olabilir. Bu öğretimsel işlem } \\
\text { doğrultusunda, öğrencilerden bir çikolata reklamı } \\
\text { hazırlamaları istenebilir. Çikolatalarına istedikleri bir marka- } \\
\text { ad bulmaları, daha sonra ürünlerini insanlara gösterip } \\
\text { tüketmelerini sağlayabilmek için bir reklam filmi hazırlamaları } \\
\text { gerektiği söylenir. Bunun üzerine ister gruplar hâlinde ister } \\
\text { tüm sınıfla aynı çikolata için bir reklam hazırlanabilir. Reklam } \\
\text { içinde yazılı unsurlar, çikolatanın kabı, rengi, çikolatanın } \\
\text { şarkısı yer alabilir. Ayrıca çocukların günlük hayatta bu } \\
\text { çikolatayı ne şekilde tüketebilecekleri ve alacakları zevki } \\
\text { gösteren bir drama etkinliği de reklam içinde yer alabilir. } \\
\text { Reklam hazırlama işlemi ile çocuklar Türkçe dersinde yazma } \\
\text { ve konuşma becerilerini istekle kullanırlar ve uygulamalı } \\
\text { şekilde becerileri kazanabilirler. }\end{array}$ & $\begin{array}{l}\text { Y.2.7 } \\
\text { K.2.2 } \\
\text { K.2.4 } \\
\text { K.2.5 } \\
\text { K.2.7 } \\
\text { K.2.8 } \\
\text { K.2.9 } \\
\text { K.3.7 }\end{array}$ \\
\hline
\end{tabular}

\section{Kendini öğretmenin yerine koyma}

Tanım: Öğrencilerin, kendilerini öğretmenin yerine koyarak o konuda nelerin öğrenilmesi gerektiğini ve nasıl öğrenilebileceğini tasarlamasıdır.

\begin{tabular}{|c|c|}
\hline Kullanımı & $\begin{array}{l}\text { Etkili Olabileceği } \\
\text { Amaç / Kazanımlar }\end{array}$ \\
\hline $\begin{array}{l}\text { Öğrencilerin sorumluluk alması öğretim sürecinde örnek } \\
\text { davranışların ve öğrenilmesi gereken konuların daha kolay } \\
\text { kazanılmasını sağlayabilir. Türkçe dersinde öğrencilerin } \\
\text { öğretmenin yerine geçip dersi yönlendirmesi de } \\
\text { öğrencilerin derse karşı güdülenme düzeylerini artırıcı bir } \\
\text { taktik-işlem olabilir. Bu uygulamaların dönem dönem } \\
\text { yapılıp alışkanlık hâline getirilmesi, öğrencilerin örnek } \\
\text { konuşma ve dinleme alışkanlıklarını edinmeleri } \\
\text { sağlanabilir. }\end{array}$ & D.2.15 \\
\hline
\end{tabular}


Resim hakkında konuşma / yazma

Tanım: Öğrencilerin gösterilen bir resimle ilgili konuşması, soru sorması ve problem oluşturmasıdır.

\begin{tabular}{lcc}
\hline \multicolumn{2}{c}{ Kullanımı } & $\begin{array}{c}\text { Etkili Olabileceği } \\
\text { Amaç / Kazanımlar }\end{array}$ \\
\hline Resim ve diğer görsel materyaller öğrencinin dersin & \\
içeriğini daha rahat anlamasını ve somutlaştırmasını & \\
sağlayabilmektedir. Ancak görsellerin seviyeye uygun & $\mathbf{K . 3 . 3}$ \\
olması gerekmektedir. Türkçe dersinde okuma veya yazma & $\mathbf{K . 5 . 1}$ \\
çalışmalarında konu ile ilgili bir resim öğrencilere gösterilip & $\mathbf{Y . 2 . 3}$ \\
bununla ilgili konuşmaları, ardından bir metinle düşünce & Y.5.1 \\
veya duygularını yazıla aktarmaları istenebilir. Ayrıca bir & \\
resimden hareketle öğrencilerin bir olayı dramatize & \\
etmeleri istenebilir. & \\
\hline
\end{tabular}

\section{Yanlışları ve nedenlerini bulma}

Tanım: Öğrencilerin, verilen bir metinde ya da yapılan bir işlemde kasıtlı olarak yapılmış olan yanlışları saptamaları ve onların neden yanlış olduğunu söylemeleridir.

\begin{tabular}{lc}
\hline \multicolumn{1}{c}{ Kullanımı } & $\begin{array}{c}\text { Etkili Olabileceği Amaç } \\
\text { / Kazanımlar }\end{array}$ \\
\hline Türkçe dersinde öğrenciler okurken, konuşurken veya & \\
yazarken yanlışlar yapabilir. Dinlerken yanlış anlayıp & $\mathbf{0 . 3 . 1}$ \\
yazarken veya konuşurken bu yanlışı sürdürebilir. Yanlışları & $\mathbf{0 . 3 . 2}$ \\
ve nedenleri bulma, bu durumda kullanılabilecek bir aktif & $\mathbf{D . 3 . 1}$ \\
öğrenme taktiğidir. Derste öğretmen bu işlemi öğrencilerin & $\mathbf{D . 3 . 2}$ \\
okumalarında, yazdıkları ürünlerde ve konuşmalarında & $\mathbf{D . 3 . 3}$ \\
kullanabilir. Okuma metni birkaç öğrenci tarafından okunur, & \\
görevlendirilen birkaç öğrenci ve öğretmen de yapılan \\
okuma yanlışlarını not eder. Ardından bu yanlış sınıfa ilan \\
edilir, sebepleri ortaya çıkarılır ve çözüm yolları önerilebilir. \\
Aynı işlem yazılı ürünlerde, sınav kâğıtlarında da \\
uygulanabilir. Örneğin, sınav kâğıtları öğrencilere dağıtılır. \\
Seçilen birkaç kâğıt üzerinde hem bilgi hem de yazım \\
yanlışları tespit edilir ve neden yanlış yapıldığı belirlenebilir. \\
\hline
\end{tabular}

\section{Önem sırasına koyma}

Tanım: Öğrencilerin, işlenen konudaki ana düşünceleri, ilkeleri ya da anahtar sözcükleri önem sırasına koymalarıdır.

\begin{tabular}{|c|c|}
\hline Kullanımı & $\begin{array}{c}\text { Etkili Olabileceği Amaç } \\
\text { / Kazanımlar }\end{array}$ \\
\hline $\begin{array}{l}\text { Duygu ve düşüncelerin önem sırasına konulması, } \\
\text { öğrencilerin duygu ve düşüncelerini yazıya dökerken } \\
\text { kazanmaları gereken önemli bir beceridir. Türkçe dersinde } \\
\text { yazma çalışmalarında ve konuşma uygulamalarında } \\
\text { öğrencilerin duygu ve düşüncelerinin önem sırasına } \\
\text { koyulması için bu işlem kullanılabilir. Öğrencilerin önem } \\
\text { sırasına koyma işlemini alışkanlık hâline getirebilmeleri için } \\
\text { bir örnek metin üzerinde çözümleme yapılabilir ya da günlük } \\
\text { yaşamla ilgili bir durumun canlandırılması istenebilir. } \\
\text { Canlandırma esnasında öğrencilerin duruma uygun } \\
\text { doğaçlamalara başvurmaları, ancak duygu ve düşüncelerini } \\
\text { en önemli olandan daha az önemli olana doğru } \\
\text { söylemelerinin gerektiği belirtilir. }\end{array}$ & $\begin{array}{c}\text { D.2.10 } \\
\text { K.1.9 } \\
0.2 .13 \\
\text { Y.1.7 }\end{array}$ \\
\hline
\end{tabular}




\section{Bulmaca}

Tanım: Öğrencilerin konu ile ilgili bulmaca hazırlamaları ya da öğretmen tarafından hazırlanmış bir bulmacayı çözmeleridir.

\begin{tabular}{lll}
\hline & Kullanımı & $\begin{array}{c}\text { Etkili Olabileceği } \\
\text { Amaç/ Kazanımlar }\end{array}$ \\
\hline Türkçe dersinde öğrencilerin okudukları metinlerde & \\
geçen anlamını bilmedikleri sözcüklerin anlamı & \\
eğlenceli şekilde öğrenmeleri için bulmacalar & $\mathbf{0 . 4 . 1}$ \\
kullanılabilir. Hem sözcük hem sözcük gruplarının & $\mathbf{0 . 4 . 3}$ \\
anlamlarını kazandırmada bulmacalar etkili bir & $\mathbf{D . 4 . 1}$ \\
öğretim materyali olabilir. Aynı zaman bulmacalar, & $\mathbf{D . 4 . 5}$ \\
dinlenen bir metinle ilgili önemli kısımların & \\
belirlenmesinde de kullanılabilir. & \\
\hline
\end{tabular}

\section{Pandomim (Sessiz Oyun)}

Tanım: Öğrencilerin, konunun başlıca kavram ve düşüncelerini sözsüz bir şekilde anlatan pandomim gösterileri hazırlamalarıdır.

\begin{tabular}{lc}
\hline Kullanımı & $\begin{array}{c}\text { Etkili Olabileceği Amaç } \\
\text { / Kazanımlar }\end{array}$ \\
\hline $\begin{array}{l}\text { Öğrenme sürecinde yaparak yaşayarak öğretimi sağlayan } \\
\text { yöntemlerin kullanımı, dil becerilerinin de kalıcı şekilde }\end{array}$ & \\
kazanılması için etkili olabilir. Bir sanat formu ve drama & \\
teknikleri içinde sınıflandırılabilen pandomimler, Türkçe & $\mathbf{K . 2 . 7}$ \\
dersinde bir metinde geçen olayları, yaşamla ilgili bir & $\mathbf{K . 2 . 8}$ \\
duyguyu, düşünceyi öğrencilere beden dili ile anlatmak & $\mathbf{K . 2 . 9}$ \\
için kullanılabilir. Öğrencilerin bu süreçte sözlü & \\
anlatımlarının yanında beden dilini kullanma alışkanlıkları \\
da geliştirilebilir. Sessiz oyunla anlatılanlar, izleyen \\
öğrencilerce not da tutulabilir. Bu şekilde farklı dil \\
becerileri de desteklenebilir.
\end{tabular}

\section{Birine öğretme}

Tanım: Uygun konularda öğrencilerin öğrenme malzemesini birbirlerine öğretmeleridir.

\begin{tabular}{|c|c|}
\hline Kullanımı & $\begin{array}{c}\text { Etkili Olabileceği } \\
\text { Amaç / Kazanımlar }\end{array}$ \\
\hline $\begin{array}{l}\text { Etkili öğrenme farklı şekillerde duyarak, görerek, } \\
\text { yazarak, yaparak ve başkasına konuyu anlatarak } \\
\text { gerçekleşebilmektedir. Türkçe dersinde aktif öğrenmeyi } \\
\text { sağlamada kullanılabilecek taktiklerden olan birine } \\
\text { öğretme, okunan metni daha iyi anlama, yazma } \\
\text { çalışmalarında, kuralları daha iyi kavratmada } \\
\text { kullanılırken konuşma becerisi de aktif hâle getirilebilir. }\end{array}$ & $\begin{array}{l}\text { K.1 } \\
\text { K.2 } \\
\text { K.3 }\end{array}$ \\
\hline
\end{tabular}




\section{işleme / ek oluşturma}

Tanım: Öğrencilerin, verilen herhangi bir konuya ilişkin ek açıklamalar, ek örnekler vermeleri, öğrendiklerini zenginleştirmeleridir.

\begin{tabular}{lcc}
\hline \multicolumn{2}{c}{ Kullanımı } & $\begin{array}{c}\text { Etkili Olabileceği Amaç / } \\
\text { Kazanımlar }\end{array}$ \\
\hline Ek oluşturma, Türkçe dersinde özellikle yazma ve & \\
konuşma çalışmalarında kullanılabilir. Öğrencilerin & \\
yaratıcı yazma alışkanlığı kazanmaları için anahtar bir & \\
düşünce, olay, kavram verilir. Metnin ilk cümlesi birlikte & $\mathbf{D . 2 . 1 7}$ \\
oluşturulur ve öğrencilerin birer cümle eklemeleri istenir. & $\mathbf{0 . 2 . 2 3}$ \\
Dinlenilen metin belirlenmiş bir yerde kesilir, öğrencilerin & $\mathbf{Y . 2 . 1 2}$ \\
birer cümle ekleyerek metni sözlü olarak tamamlamaları & \\
istenebilir. & \\
\end{tabular}

\section{Tersini yapma}

Tanım: Öğrencilerin yapılması gerekenlerin, kuralların tersini yapacakları durumların tasarlanmasıdır.

\begin{tabular}{lc}
\hline Kullanımı & $\begin{array}{c}\text { Etkili Olabileceği Amaç } \\
\text { / Kazanımlar }\end{array}$ \\
\hline Öğrenciler öğretim sürecinde beklenmedik, özgürce hareket & \\
edebilecekleri çalışmalardan hoşlanırlar. Türkçe dersinde \\
okuma, yazma, konuşma sürecinde tersini yapma taktiği \\
dersi çekici, etkili ve katılımlı hâle getirebilir. Bu açıdan \\
öğrenci okunan bir metinde, dinlenilen bir konuda \\
söylenilenlerin tersini düşünüp bunu yazıya dökebilir veya \\
sözlü olarak anlatabilir. Günlük yaşamla ilgili öğrencilere \\
sözlü yönergeler verilir, ancak tüm öğrencilerin bu \\
yönergelerin tersini yapması istenebilir. Sınıfta bir aktif \\
öğrenme süreci oluşur, öğrenciler bu süreçte derste \\
öğrenmeleri gereken konuları, becerileri ve alışkanlıkları \\
kalıcı şekilde kazanırlar.
\end{tabular}

\section{Ders günlüğü tutma}

Tanım: Öğrencilerin, belirli aralıklarla, üç-dört ders saatinde bir ya da ünitede bir durup öğrendikleri ile ilgili düşüncelerini, olayları ve izlenimlerini kaydetmeleridir.

\begin{tabular}{lcc}
\hline \multicolumn{1}{c}{ Kullanımı } & $\begin{array}{c}\text { Etkili Olabileceği Amaç / } \\
\text { Kazanımlar }\end{array}$ \\
\hline Öğrencilerin derste öğrendiklerinin kalıcı olabilmesi için & \\
tekrara, tekrar edebilmek için de notlara ihtiyaç & \\
duyulmaktadır. Türkçe dersinde özellikle yazım kuralları ve & $\mathbf{0 . 1 . 5}$ \\
diğer teorik bilgilerle ilgili, ayrıca konuşma, dinleme & $\mathbf{K . 3 . 1 2}$ \\
etkinlikleri ile ilgili öğrencilerin ders günlükleri tutması ve & $\mathbf{D . 1 . 4}$ \\
bunları okuması temel dil becerilerinin kalıcı şekilde & $\mathbf{Y . 5 . 5}$ \\
kazanılması için örnek bir taktik olabilir. Öğretmen Türkçe & $\mathbf{Y . 5 . 6}$ \\
dersinde öğrencilere bir edebî tür olan günlükleri tanıtırken & Y.5.9 \\
ders günlüklerinin de olabileceğini ve nasıl kullanılacağını \\
aktarabilir. Türkçe dersinde özellikle yazma çalışmalarında ve \\
konuşma, dinleme etkinliklerinde öğrencilerin öğrendiklerini \\
okuldan sonra günlüklerine aktarmaları istenebilir. \\
Öğrencilerin tuttukları günlükler belirli aralıklarla sınıfta \\
tekrar edilir.
\end{tabular}




\section{Poster ya da afiş hazırlama}

Tanım: Öğrencilerin, işlenen konunun önemli noktalarını tanıtan bir poster (Duvara asılan büyük boy resim) veya afiş (Bir şeyi duyurmak veya tanıtmak için hazırlanan, kalabalığın görebileceği yere asılmış, genellikle resimli duvar ilanı.) hazırlamalarıdır.

\begin{tabular}{|c|c|}
\hline Kullanımı & $\begin{array}{c}\text { Etkili Olabileceği Amaç } \\
\text { / Kazanımlar }\end{array}$ \\
\hline $\begin{array}{l}\text { Türkçe dersinde ders kitaplarında da kullanılan resimler ve } \\
\text { diğer görsel unsurlar öğrenilenlerin kalıcılığını artırmak } \\
\text { içindir. Öğrencilerden okudukları veya dinledikleri bir } \\
\text { metinle ilgili bir poster ya da afiş hazırlamaları istenir. } \\
\text { Hazırladıkları afişe ad koymaları istenebilir. Afiş ya da poster } \\
\text { hazırlama bireysel olabileceği gibi grup çalışması hâlinde de } \\
\text { yapılabilir. Farklı öğrencilere farklı afişler dağıtılıp bununla } \\
\text { ilgili bir yazı kaleme almaları istenebilir. Afiş ya da posterden } \\
\text { hareketle canlandırmalara başvurulabilir. Bu uygulama ile } \\
\text { öğrencilerin okudukları metni daha iyi anlamaları ve } \\
\text { değerlendirmeleri, yazılanları değerlendirmeleri ile farklı } \\
\text { uygulamalarla dinleme ve konuşma becerilerinin gelişmesi } \\
\text { de sağlanabilir. }\end{array}$ & Y.2.7 \\
\hline
\end{tabular}

\section{Mektup yazma}

Tanım: Öğrencilerin, öğrendikleri konularda birbirlerine, tanımadıkları insanlara ya da ünlü kişilere mektup yazmalarıdır.

\begin{tabular}{lc}
\hline \multicolumn{3}{c}{ Kullanımı } & $\begin{array}{c}\text { Etkili Olabileceği } \\
\text { Kazanımlar }\end{array}$ \\
\hline Türkçe derslerinde öğrencilere güzel ve doğru yazma & \\
alışkanlığı kazandırmak için aktif öğrenme taktik- \\
işlemlerinden olan mektup yazma kullanılabilir. Öğrencilere \\
okudukları bir metinde geçen önemli bir kişiye, tarihî bir \\
şahsiyete mektup yazmaları, duygu, düşünce ve isteklerini \\
açık bir şekilde anlatmaları istenebilir. Bu taktik sınıf içinde \\
bir oyun şeklinde de tasarlanabilir. Sınıf içinde bazı \\
öğrencilere alanında tanınmış bir şahsiyetle ilgili roller \\
dağıtılır, kısa diyaloglarla yaşamları anlatılır. Diğer \\
öğrencilerin bu k.2.2 \\
anlatmaları, aynı zamanda rolleri üstlenen öğrencilerin bu \\
mektuplara cevap vermesi sağlanır. Bu canlandırma \\
sürecinde sınıf için bölünmüş sahne ve donuk imge gibi \\
drama teknikleri de kullanılabilir.
\end{tabular}

\section{Gazete çıkarma}

Tanım: Öğrencilerin işlenen konu ile ilgili haber, makale, başyazı, karikatür, şiir, mektup vb. içeriği olan, okulda ve çevrelerinde dağıtabilecekleri öğretim içerikli gazeteler oluşturmalarıdır.

\begin{tabular}{lc} 
Kullanımı & $\begin{array}{c}\text { Etkili Olabileceği } \\
\text { Amaç / Kazanımlar }\end{array}$ \\
\hline Okuma alışkanlığı, bireye hayat boyu fayda sağlayacak & \\
ve gerekli olabilecek bir alışkanlıktır. Bu nedenle Türkçe & \\
dersinde işlenecek konularla, yapılacak etkinliklerle, & Y.1.1 \\
önemli günlerle, okunabilecek kitaplarla, takip & Y.2.1 \\
edilebilecek film, tiyatro, konser, konferanslarla, & Y.2.2 \\
şarkılarla vb. ilgili bir sınıf veya ders gazetesi çıkarılması & Y.2.7 \\
etkili bir öğretimsel işlem olabilir. Gazete için & Y.5.7 \\
öğrencilerin araştırma yapması, okuması, öğretmenleri & Y.5.8 \\
ve yetişkinlerle konuşması, not alması, rapor tutması ve & \\
topladıklarını görsel bir materyal hâline getirmesi & \\
lazımdır. &
\end{tabular}




\section{Öğrendiklerini listeleme}

Tanım: Öğrencilerin, neleri öğrenmeleri gerektiğinin farkına varmasını sağlayan bir taktiktir.

\begin{tabular}{|c|c|}
\hline Kullanımı & $\begin{array}{c}\text { Etkili Olabileceği Amaç / } \\
\text { Kazanımlar }\end{array}$ \\
\hline $\begin{array}{l}\text { Öğretim sürecinde öğrenilenlerin kalıcı olarak } \\
\text { kullanılabilmesi yapılan bütün öğretim ve öğrenme } \\
\text { eylemlerinin düzenli olmasına bağlıdır. Bu bağlamda aktif } \\
\text { öğrenme sürecinde kullanılabilecek taktik-işlemlerden biri } \\
\text { olarak öğrendiklerini listeme Türkçe dersinde kullanılabilir. } \\
\text { Türkçe dersinde öğrencilerin gerek beceriye dayalı gerekse } \\
\text { bilgiye dayalı öğrendiklerini listeleyerek bu listelerin yer yer } \\
\text { derste sunulması sağlanabilir. Okuma metinlerindeki olay, } \\
\text { şahıs, kişi, mekan vb. unsurlar, yazma çalışmalarında } \\
\text { düşünceler, teoriler, kurallar vb., konuşma eyleminde konu } \\
\text { ile ilgili örnekler, düşünceler vb listelenebilir. }\end{array}$ & $\begin{array}{c}\text { D.2.10 } \\
\text { O.2.12 } \\
\text { Y.1.7 } \\
\text { K.1.9 }\end{array}$ \\
\hline
\end{tabular}

\section{Görüş tarama}

Tanım: Öğrencilerin, ilgililerin belli bir problem ya da konu hakkındaki düşüncelerini anket, ölçek vb. araçlarla toplayıp topladıkları verileri çözümleyip sonuçlarını sunmalarıdır.

\begin{tabular}{lc}
\hline \multicolumn{1}{c}{ Kullanımı } & $\begin{array}{c}\text { Etkili Olabileceği Amaç / } \\
\text { Kazanımlar }\end{array}$ \\
\hline Belirli bir konudaki yetkili ve ilgili kişilerin görüşlerinin öğrenciler & \\
tarafından taranması öğrencilerin konuyu daha hâkim bir & \\
şekilde öğrenmelerini ve öğrendiklerini kullanmalarını & D.3.1 \\
sağlayabilir. Türkçe dersi kapsamında da mesela öğretmenlerin & D.3.2 \\
edebî türlerinin derste kullanımı ile ilgili görüşleri öğrenciler & $\mathbf{D . 5 . 1}$ \\
tarafından taranabilir. Bu tarama açık uçlu basit sorularla & $\mathbf{D . 5 . 2}$ \\
yapılabilir. Öğretmen bu çalışmalarda destek olmalıdır. Bunun & $\mathbf{D . 5 . 3}$ \\
yanında öğretim sürecinde farklı şekillerde de görüş tarama & $\mathbf{D . 5 . 4}$ \\
taktiği kullanılabilir. Herhangi bir konuda öğrencilerin farklı & $\mathbf{0 . 3 . 1}$ \\
görüşleri olabilir. Türkçe dersinde öğrencilere okunan bir & $\mathbf{0 . 3 . 2}$ \\
metinle veya konuşulan bir haberle ilgili görüşleri sorulabilir. Bu & $\mathbf{0 . 5 . 2}$ \\
işlem tüm öğrencileri kapsayacak bir görüş taraması şeklinde & $\mathbf{0 . 5 . 3}$ \\
yapılırsa daha eğlenceli ve ilginç olabilir. Ders dışında & $\mathbf{0 . 5 . 6}$ \\
öğrencilerin çeşitli konferans, konser, dinleti vb. toplantılara & \\
katılıması veya medyadan takip etmesi istenebilir. Bunlarla ilgili & \\
görüşleri taranabilir. Günlük yaşamda okudukları veya & \\
dinledikleri ürünlerle ilgili görüşleri de taranabilir. & \\
\hline
\end{tabular}




\section{Sessiz gösterim}

Tanım: Öğretmenin konu ile ilgili açıklamaları sessizce, konuşmadan göstermeye çalışmasıdır.

\begin{tabular}{|c|c|}
\hline Kullanımı & $\begin{array}{c}\text { Etkili Olabileceği Amaç / } \\
\text { Kazanımlar }\end{array}$ \\
\hline $\begin{array}{l}\text { İlköğretim seviyesinde öğrencilerin görsel materyalleri } \\
\text { yorumlayarak anlatılanları daha net ve kalıcı şekilde } \\
\text { öğrenmeleri sağlanabilir. Bu şekilde öğrencilerin bilişsel üst } \\
\text { düzey becerileri geliştiği gibi okuma, konuşma, yazma gibi dil } \\
\text { becerileri de geliştirilebilir. Öğretmen dersteki açılamaları } \\
\text { sessiz bir şekilde anlatarak öğrencilerin dikkatini toplayabilir, } \\
\text { izleyen öğrencileri daha sonra aynı konuda konuşturabilir. } \\
\text { Bunun yanında, bir sinema filminin veya şarkının video klibinin } \\
\text { Türkçe derslerinde sessiz gösterim taktik-işlemi için kullanımı } \\
\text { dersi eğlenceli bir hâle getirebilir. Öncelikle, bu materyallerin } \\
\text { sözsüz sadece görüntülerinin öğrencilere aktarılması sağlanır. } \\
\text { Ardından öğrencilerin bu görüntülerden hareketle filmdeki } \\
\text { diyalogları tahmin etmeleri ve doğaçlama bir şekilde ifade } \\
\text { etmeleri istenebilir. Aynı şekilde video klipte sadece görüntüsü } \\
\text { olan şarkıcının seslendirdiği şarkı da öğrencilerce } \\
\text { seslendirilebilir. Sözlerin seçimi öğrenciye bırakılır. Bu süreçte } \\
\text { öğrenciler sınıf önünde şarkıyı veya filmdeki diyalogları } \\
\text { seslendirebilir ya da rol oynama tekniği ile kısa bir olayı } \\
\text { canlandırabilirler. }\end{array}$ & D.2.(tüm kazanımlar) \\
\hline
\end{tabular}

\section{Anahtar düşünceleri bulma}

Tanım: Öğrencilerin işlenen konudaki başlıca kavramları, ilkeleri ve düşünceleri bulmasıdır.

\begin{tabular}{lc}
\hline \multicolumn{1}{c}{ Kullanımı } & $\begin{array}{c}\text { Etkili Olabileceği Amaç } \\
\text { / Kazanımlar }\end{array}$ \\
\hline Türkçe dersinde okunan bir metni daha iyi anlamak için & $\mathbf{0 . 2 . 2}$ \\
metnin çözümlenmesi gerekir. Anahtar düşünceleri bulma, & $\mathbf{0 . 2 . 3}$ \\
okuma sürecinde metni daha iyi anlamayı sağlayabilecek bir & $\mathbf{0 . 2 . 4}$ \\
taktik-işlem olarak kullanılabilir. Öğrencilerden okunan bir & $\mathbf{D . 2 . 2}$ \\
metnin ana düşüncelerini bulmaları istenir. Veya bir konuşma & $\mathbf{D . 2 . 3}$ \\
dinletilir. Bu konuşmadaki anahtar düşünceler tespit ettirilir. & $\mathbf{D . 2 . 4}$ \\
Bu düşüncelerden hareketle öğrencilerin yeni yazı yazmaları & \\
istenebilir. & \\
\hline
\end{tabular}

\section{Eksiklerin nasıl tamamlanacağını tartışma}

Tanım: Eksik öğrenme ürünlerinin sınıfa sunulması ve öğrencilerin, eksikliklerin giderilmesi için öneride bulunmasıdır.

\begin{tabular}{lcc}
\hline \multicolumn{2}{c}{ Kullanımı } & $\begin{array}{c}\text { Etkili Olabileceği } \\
\text { Amaç / Kazanımlar }\end{array}$ \\
\hline Türkçe dersinde yarım bırakılmış materyallerin & \\
tamamlanması kullanılabilecek bir tekniktir. Eksik & $\mathbf{D . 2 . 1 7}$ \\
bırakılmış metin yazarak, konuşarak tamamlatılabilir. Bu & $\mathbf{0 . 2 . 2 4}$ \\
uygulama kapsamında eksik kalan kısımların nasıl & \\
tamamlanacağı sınıfça tartışılarak bulunabilir. Bu şekilde & \\
tüm sınıf düşünceleri sözlü olarak veya yazarak & \\
belirtebilir. & & \\
\hline
\end{tabular}




\section{Hiç söylenmemiş bir şey söyleme}

Tanım: Öğrencilerin, öğrendikleri ile ilgili daha önce sınıfta hiç söylenmemiş bir şey söylemeleridir.

\begin{tabular}{lc}
\hline \multicolumn{1}{c}{ Kullanımı } & $\begin{array}{c}\text { Etkili Olabileceği Amaç } \\
\text { / Kazanımlar }\end{array}$ \\
\hline $\begin{array}{l}\text { Türkçe dersi içinde öğrencilerin dikkatini toplamak ve } \\
\text { okunan metni daha iyi anlamaları için veya herhangi bir } \\
\text { kuralla ilgili o ana kadar hiç söylenmemiş bir şey söylemeleri }\end{array}$ & Y.5.1 \\
istenebilir. Öğrencilere özgür ve özgün şekilde düşünceleri & $\mathbf{Y . 5 . 8}$ \\
ifade etmeleri söylenebilir. Bu uygulama ile yaratıcı ve & $\mathbf{K . 5 . 3}$ \\
eleştirel düşünme becerileri gelişirken konuşma becerilerine & \\
de katkıda bulunulabilir. & \\
\hline
\end{tabular}

\section{Sonuç}

Dil eğitimi ve öğretiminde devamlı değişen ve dinamik bir yapı söz konusudur. Bu bağlamda dil eğitiminde, çağın değişimlerine ve toplumun beklentilerine uygun olarak süreklilik arz edecek düzenlemelere gidilmelidir. Bu düzenlemeler, öncelikle öğretim sürecinin ana unsurları olan strateji, yöntem ve teknikler üzerinde yapılmalıdır. Değişen eğitim yaklaşımlarına uygun, dilin mantığına göre öğretimi gerçekleştiren, toplumun beklentilerini karşılayacak bilgi ve becerilerle öğrencileri donatan öğretim süreçleri planlanmalıdır. Dil öğretiminin içerik, materyal, yöntem ve tekniklerinin belirlenmesi bununla birlikte öğretmenlerinin yetiştirilmesinde bu ayrıntıya dikkat edilmelidir. Dil öğretimi yöntem ve teknikleri, öğrencinin ve eğitim içeriğinin özelliklerine hizmet ederken aktif katılımı, eleştirel yaklaşabilmeyi, yaratıcı çözümler üretmeyi, uygulamaya dayalı olmayı, günlük yaşamdan örnekler almayı ve dilin yapısını tam olarak kavratmayı göz ardı etmemelidir (Maden 2010: 771). Aktif öğrenme teknik, öğretimsel iş ve taktikleri dil öğretiminde / eğitiminde kalıcı öğrenmeyi, aktif katılımı, çözüm üreterek öğrenmeyi, uygulamalı olarak beceri kazanmayı, akranlarla birlikte öğrenmeyi, iş birliği yapabilmeyi ve yaratıcı bakabilmeyi kullanıma sunmaktadır.

Öğretim stratejisi, yöntemi, tekniği kısaca biçimi, belirlenmiş amaçlara ulaşııması yani öğrenmenin tam ve etkili bir şekilde gerçekleşmesinde önemli bir rol oynar (Büyükkaragöz, 1997). Aktif öğrenme taktik ve öğretimsel işleri üzerinde yapılan değerlendirmede, örnek uygulamalardan hareketle temel becerilerinin eğitiminde ne şekilde kullanılabilecekleri gösterilmeye çalışılmıştır. Temel dil becerilerinin eğitimi için birtakım önerilerde bulunulmuştur. Aktif öğrenme öğretimsel iş ve taktikleri dinleme, konuşma, okuma ve yazma becerilerinin bütününde kullanılabilecek bir niteliğe sahiptir. Örneklenen öğretim durumlarının dışında da bu taktik ve öğretimsel işler kullanılabilir. Belirlenen iş ve taktiklerin dışında kalan diğer öğretimsel iş ve taktikler de temel dil becerilerinin öğretiminde yardımcı olabilecek niteliktedir. Aktif öğrenme öğretimsel iş ve taktikleri, temel dil becerilerinin öğretiminde diğer öğretim yöntem ve teknikleri ile birlikte destekleyici olarak kullanılabileceği gibi dil becerilerinin öğretim sürecinde öğretim biçimi olabilecek işleve de sahiptir.

Aktif öğrenme öğretim iş ve taktiklerinin okuma, dinleme, konuşma ve yazma becerilerinin eğitiminde kullanımı ile ilgili değerlendirme sonucunda, Türkçe öğretiminin özel amaç ve kazanımlarına hizmet ettiği ve etkili birçok öğrenme olanağını sunacağı görülmüştür. Illgili alan yazınında aktif öğrenmenin dil öğretimindeki başarı, tutum, motivasyon vb. birçok değişken üzerinde olumlu etkisinin olduğuna dair araştırma sonuçları da araştırmada gerçekleştirilen değerlendirmeleri ve önerileri desteklemektedir. Özerbaş, Tabak ve Ahi (2010)'nin aktif öğrenme ortamının ilköğretim öğrencilerinin Türkçe dersi akademik başarısına ve motivasyonuna etkisini araştırdıkları çalışmalarında aktif öğrenmenin Türkçe dersi başarısında ve dersteki motivasyon üzerinde etkili olduğu sonucuna varılmıştır. Aynı şekilde Koç (2005)'un çalışmasında aktif öğrenmenin ilköğretim sekizinci sınıf öğrencilerinin okuduğunu anlama başarıları ve eleştirel düşünme becerileri üzerinde geleneksel öğretim yöntemlerine göre daha etkili olduğu saptanmıştır. Boas (1989), Dolinsky (2001) ile Lena ve arkadaşlarının (2001) yaptıkları araştırmaların sonucunda da aktif öğrenmenin öğrenme sürecine katıımı, iletişim ve güdülenme düzeyini artırdığı / olumlu etkilediği tespit edilmiştir. 
Öğretimde yöntem ve teknikler ne kadar önemli ise bunların seçimi ve uygunluğu da bir o kadar önemlidir. Öğretmenlerin yöntem konusunda seçici olabilmeleri çok farklı yöntem ve teknikleri tanımaları ve kullanabilmelerine bağlıdır (Demirel, 1999). Bu nedenle Türkçe öğretmenlerine lisans eğitimi döneminde aktif öğrenme gibi çağdaş eğitim yaklaşım ve yöntem-teknikleri tanıtılmalıdır. Ayrıca bu yeni öğretim biçimleri ile ilgili uygulamalarda da bulunulmalıdır. Türkçe Eğitimi Bölümü lisans programındaki Öğretim Ilke ve Yöntemleri, Özel Öğretim Yöntemleri I-II, Anlama Teknikleri I: Okuma Eğitimi, Anlama Teknikleri II: Dinleme Eğitimi, Anlatma Teknikleri I: Konuşma Eğitimi, Anlatma Teknikleri II: Yazma Eğitimi dersleri bu açıdan faydalı şekilde yürütülmelidir. Özellikle Öğretim Ilke ve Yöntemleri dışındaki alan eğitimi derslerinde teorik ve uygulamalı çalışmaların yapılması gerekmektedir. Bu derslerde, çağdaş yaklaşım, yöntem ve tekniklerin tanıtımı ve Türkçe dersinde nasıl uygulanacağı hakkında öğretmen adaylarına bilgi ve deneyim kazandırılmalıdır. Görev yapmakta olan Türkçe öğretmenleri, aktif öğrenme ve diğer çağdaş yaklaşımlar konusunda yeterli bilgi ve donanıma sahip olmalıdır. Bu nedenle görev yapmakta olan öğretmenlere aktif öğrenme ile ilgili (ve diğer yaklaşımları tanıtııı) hizmet içi eğitim seminerleri düzenlenmeli, okullar bu konuda kaynak ve araç-gereç bakımından desteklenmelidir. Aktif öğrenme ile ilgili öğretmenlere yönelik, hizmet içi eğitimler toplantılar şeklinde olabileceği gibi, artık millî eğitim sistemindeki teknolojik değişimle birlikte akıllı tahtalar kullanılarak genel ağ üzerinden de yapılabilir.

\section{Kaynakça}

Açıkgöz, K. Ü. (2006). Aktif öğrenme. İzmir: Biliş Yayıncılık.

Boas, H.D. (1989). Implementing a school-based staff development project designed to promote active learning and increase student interest in elementary social studies: A case study. Dissertation Abstract International, 49(7),31(DA713).

Bonwell, C. \& Eison, J. A. (1991). Active learning: creation excitement in the classroom. EricHigher Education Reports. Eric No: ED340272.

Büyükkaragöz, S. (1997). Eğitimde program geliş̧tirme. Konya: Öz Eğitim Yayınları.

Demirel, Ö. (1999). Öğretme sanatı. Ankara: PegemA Yayıncılık.

Dewey, J. (1938/1997). Experience and education. New York: Macmillan Co

Dewey, J. (1983). How We Think? Lexington, Mass.: D.C. Heath.

Dolinsky, B.(2001). An active approach to teaching statistics. Teaching of Psychology, 28 (1), 55-56.

Ercan, O. (2004). Bir öğrenme süreci olarak aktif öğrenme. Bilim ve Aklın Aydınlığında Eğitim Dergisi, (5), 54-55.

Freeman-Larsen, D. (1997). Chaos/complexity science and second language acquisition. Applied Linguistic. 18 (2), 141-65.

Güçlü, E. (2007). Sınıf yönetiminde aktif öğrenme tekniklerinin öğrenci başarısındaki ve tutumundaki önemi. Yayımlanmış Yüksek Lisans Tezi, Yeditepe Üniversitesi Sosyal Bilimler Enstitüsü, Ankara.

Kalem, S ve Fer, S. (2003). Aktif öğrenme modeliyle oluşturulan öğrenme ortamının öğrenme, öğretme ve iletişim sürecine etkisi. Kuram ve Uygulamada Eğitim Bilimleri, 3 (2), 433-461.

Koç, C.(2007). Aktif öğrenmenin okuduğunu anlama, eleştirel düşünme ve sınıf içi etkileşim üzerindeki etkileri. Yayımlanmamış doktora tezi, Dokuz Eylül Üniversitesi Eğitim Bilimleri Enstitüsü.

Kyriacou C.,Manower B. \& Newson G. (1999). Active learning of secondary school mathematics in botswana. Curriculum, $20(2), 125-130$

Lena, A. N., Bergendahl, C, Stenlund, P., \& Tibell, T. (2001). An open laboratory experiment, a method for active learning: Biochemistry education for millennium. Dissertation Abstract International, 53 (7), 311, (DA2934). 
Liu, Q.,\&Shi, J. (2007). An analysis of language teaching approaches and methods -effectiveness and weakness. US-ChinaEducationReview, 4 (1).

Maden, S. (2010). The effect of jigsaw IV on the achievement of course of language teaching methods and techniques. EducationalResearchandReviews, December, 5(12), 770-776.

Maden, S. (2011). Türkçe öğretimi ve aktif öğrenme. Ankara: PegemA Yayıncılık.

Martyn, M. (2007). Clickers in the classrooms: an active learning approach. Educause Quarterly, 2, 71-74.

Özerbaş, M.A., Tabak, H., ve Berat A. (2010). Aktif öğrenme ortamının ilköğretim 5. sınıf öğrencilerinin Türkçe dersi akademik başarısına ve motivasyonuna etkisi. International Conference on New Trends in Education and Their Implications 11-13 November, Antalya-Turkey.

Page, M. (1990). Active learning: historical and contemporary perspectives. Printing doctoral thesis, University of Massachusetts, USA.

Pillay, H. (2001). Aktif öğrenme ve yaratıcı öğrenmeyi anlamak. Yansıma, (14), 13.

Saban, A. (2005). Öğrenme öğretme süreci: yeni teori ve yaklaşımlar. Ankara: Nobel Yayıncılık.

Slavin, R. E. (2003). Educational psychology the oryandpractice. USA: Allynand Bacon Press. 